\title{
Prof. Dr. Hüseyin Aydın'ın Hayatı ve Çalışmaları
}

\author{
Süleyman Sayar \\ Dr. Öğr. Üyesi, Bursa Uludağ Üniversitesi, İlahiyat Fakültesi, Dinler Tarihi Ana Bilim Dalı \\ Bursa/Türkiye \\ ssayar1956@hotmail.com \\ http://orcid.org/0000-0003-1051-6724
}

\begin{abstract}
Akademik uğraş alanı felsefe olan bir ilâhiyatçı sıfatıyla Prof. Dr. Hüseyin Aydın, 87 yıllık ömrünü tamamlayarak 2021'in Ağustos'unda ebedî âleme göçtü. Burada objektif olarak hayatı ve çalışmaları sunulacak; ancak akademik nitelik iddiasından uzak bir malzemenin (yıllık kayıtları) izin verdiği ölçüde düşünceleri ve kişiliğinin bazı yönleri tezâhür ettirilmiş olacaktır.
\end{abstract}

\section{Hayat1}

Hüseyin Aydın 1938 yılında (gerçekte 15.02.1934) Antalya/Elmalı'da doğdu. Aynı ilçede ilköğrenimini ve hâfızlığını tamamladı. 1961 yılında Antalya İmam Hatip Okulu'ndan, daha sonra Antalya Lisesi'nden mezun oldu. 1966'da İstanbul Yüksek İslâm Enstitüsü'nü ve 1970'de İstanbul Üniversitesi Edebiyat Fakültesi Felsefe Bölümü'nü bitirdi. Bitirme tezi Alman filozofu “Nicolai Hartmann'da Teleoloji”dir. Diyanet İşleri Başkanlığı'nın çeşitli kademelerinde görev yaptı (1961-1971). Bu çerçevede İmam-Hatiplik (1961-1967), Fatih merkez vaizliği (1967-1968) görevlerinde bulundu. 1968-1970 yıllarında yedek subay olarak askerliğini yaptı. Din İşleri Yüksek Kurulu Raportörlüğü (1970-1971) görevinden sonra Ankara Üniversitesi ìlâhiyat Fakültesi İslâm Felsefesi Kürsüsü'ne asistan oldu (1971). Kendi ifadesine göre, hocası Prof. Dr. İbrahim Agâh Çubukçu'nun yönlendirmesiyle isminden başka hiçbir yönünü bilmediği, fakat çalışmaları ilerleyince "gerçek anlamda ve çok yönlü bir düşünür" olduğunu gördüğü Sünnî mutasavvıf Muhâsibî üzerine hazırladı̆̆ı tezle "doktora"sını tamamladı (1975). Arap ülkelerinde (1973) ve özellikle doçentlik tezi için Almanya'da (1978-1980) mesleği/alanı ile ilgili araştırmalarda bulundu. 1981'de Sistematik Felsefe Kürsüsü'nde, kendi tabiriyle "modern ateizmin en popüler simalarından" ve "ekstrem bir ateist" olan Nietzsche üzerine hazırladı̆̆ı tezle (Metafizikçi Olarak Nietzsche) Felsefe Tarihi “doçent”i oldu. 12 Eylül 1980 askerî darbesinden sonra yükse-

Geliş Tarihi/Received Date: 15.12 .2021

Kabul Tarihi/Accepted Date: 18.12.2021

Vefa Notu /Tributary Note

Atıf/Citation: Sayar, Süleyman. “Prof. Dr. Hüseyin Aydın'ın Hayatı ve Çalışmaları”. Uludağ Üniversitesi İlahiyat Fakültesi Dergisi 30/2 (Aralık 2021), 653-665. https://doi.org/10.51447/uluifd.1040083 
köğretimin yeniden yapılandırılması ve Yüksek İslâm Enstitülerinin fakülteye dönüştürülmesi sürecinde 2547 Sayılı YÖK Kanunu gereği Uludağ Üniversitesi İlâhiyat Fakültesi'ne İslâm Felsefesi Ana Bilim Dalı öğretim üyesi olarak naklen atandı (01.02.1983). Bu atama ile fakülte ilk defa doçent unvanlı bir öğretim üyesine kavuştu. "Yaratılış ve Gayelilik (Teleoloji)" konulu takdim teziyle 1988 yılında profesörlüğe yükseltildi. Bu çalışmasında din, ilim ve felsefenin verilerinden hareketle yaratılış ve gayeliliğe bir açıklama getirirken tercihinin "İslâm İmanı" olduğunu; konuya, iman çerçevesinde ilmî ve felsefî bir boyut da ekleyerek, "daha anlamlı bir tasvir ve açılama getirmeye çalıştığı"nı belirtmiştir.

Hüseyin Aydın, yine kendi ifadesine göre, mensubu olmakla gurur duyduğu ve fakülteleşmesinde, akademik geleneğin oluşmasında emek verdiği ìlâhiyat Fakültesi'nde öğretim üyeliğini sürdürürken çeşitli konumlarda yöneticilik yaptı. Nihayet 1993 Mayıs'ında aynı fakülteye dekan olarak atandı (14.05.1993). Üç yılı doldurduktan sonra -bir süre vekâleten dekan yardımcısı tarafından yürütülen dekanlığa- yeniden ataması yapıldı (05.09.1996). Ancak ikinci dönem dekanlık süresini tamamlayamadan görevinden ayrılmak zorunda kaldı (07.07.1997). ${ }^{1}$ Toplam dört yıl dekanlık yapmış olan Aydın, Uludağ Üniversitesi İlâhiyat Fakültesi'ne atanan İlâhiyatçı ilk dekan olma özelliğine de sahiptir. 2002 yılında emekli oldu. Emeklilik sonrası da bilimsel çalışmalarını sürdürdü. Özellikle akademik ilerleme süreciyle ilgisi olmayan Laiklik ve Atatürkçülük konulu kitaplarını emeklilik sonrası yayımladı. Samimi ve ilmî bir çalışma ortaya koyma isteğinin ötesinde, muhtemelen görevde iken yaşadığı bazı sıkıntıların bu noktadaki görüşlerini kamuya sunmasında etkili olduğu söylenebilir.

Aydın, Bursa'da ikamet ettiği yeni yerleşim bölgesinde hayrî bir uğraş alanı olarak önemsediği cami inşâ faaliyetlerinde bulundu. Esasen ilk cami yapımını Almanya'da bulunduğu yıllarda gerçekleştirdiği kendisine dayanan bir bilgidir. Sonra bu süreç, dekanlığı döneminde Bursa İlâhiyat Fakültesi Camii'nin inşâ çalışmalarıyla devam etti. Bu çerçevede büyük gayretleri oldu. Nihayet emeklilik sonrası -2007'den itibaren- Ertuğrulkent Camileri Yaptırma ve Yaşatma Derneği Başkanı sıfatıyla Hacı Ömer Raca, Hâfız Tayyar, Ertuğrulkent ve Batıkent camilerinin yapımını gerçekleştirdi. $^{2}$

Arapça, Almanca ve kısmen İngilizce, Latince, Farsça bilen Hüseyin Aydın evli olup -kendi ifadesine göre- bir oğul ve iki torun sahibidir. 15.08.2021 tarihinde vefât eden Aydın'ın cenazesi, Antalya/Elmalı'da Ketenci Ömer Paşa Camii'nden kaldırılarak Baltası Gedik Mezarlığı'nda defnedilmiştir (17.08.2021).

\footnotetext{
1 Dekan olarak atanma tarihleri konusunda bk. Mustafa Öcal, "25. Y1lında Uludağ Üniversitesi İlâhiyat Fakültesi”, Uludağ Üniversitesi İlahiyat Fakültesi Dergisi, 9/9 (2000), 17-18; a.mlf., Kuruluşundan Günümüze Uludağ Üniversitesi İlâhiyat Fakültesi (28 Kasım 1975 - 28 Kasım 2005) (İstanbul: Özal Matbaası, 2006), 50-51.

2 Cami yapımına dair kimi bilgiler dernekte birlikte çalıştıkları Bursa İlahiyat Vakfı müdürü Yusuf Demiröz tarafından sağlanmıştır.
} 


\section{2. Çalışmaları}

\subsection{Kitaplar}

\subsubsection{Yayımlanmış Olanlar}

- Muhasibînnin Tasavvuf Felsefesi (İnsan-Psikoloji-Bilgi-Ahlâk Görüşü), Ankara: Pars Matbaacilik, 1976).

- Metafizikçi Olarak Nietzsche, Bursa: Uludağ Üniversitesi Basımevi, 1984; 2. bs., İstanbul: DBY Yayınları, 2020.

- İlim Felsefe ve Din Açısından Yaratılış ve Gayelilik (Teleoloji), Ankara: Diyanet İşleri Başkanlığı Yayınları, 1987, 1991, 1996, 1999, 2002, 2004, 2012.

- Yüksek İslâm Enstitüleri - Akademisyenlik Özlemi ve Akademisyenliğin Anatomisi, Bursa: y.y., 2000.

- Aydınlanmanın Ana Kucağında Laiklik ve Atatürkçülük, Bursa: Emin Yayınları, 2010; 2. bs., Bursa: Sentez Yayınları, 2015.

- Atatürk'ün Usûl ve Felsefesinden Cumhuriyetin Resmî İdeolojisine, Antalya: Akdeniz Üniversitesi Matbaası, 2017..

\subsubsection{Yayımlanmamış Olanlar}

Nietzsche kitabının DBY Yayınları'ndan çıkan ve yukarıda belirtilen yeni basımında (İstanbul 2020), biyografisine ek olarak Hüseyin Aydın'ın kısaca eserleri sıralanmakta; ardından yayıma hazırlanmakta olan iki yeni çalışmasından söz edilmektedir: ${ }^{3}$

- Masonluk: Dindar Dinsizlik mi, Dinsiz Dindarlık mı?

- Bir Dünya Görüşü Olarak Atatürkçülük ve Türk Milleti.

\subsection{Makaleler - Bildiriler - Konuşmalar}

Hüseyin Aydın, makalelerini ağırlıklı olarak Ankara Üniversitesi İlahiyat Fakültesi ve Uludağ Üniversitesi İlâhiyat Fakültesi dergilerinde, ayrıca Diyanet Dergisi'nde yayımladı. Diyanet İşleri Başkanlı̆̆g'nın organize ettiği Kutlu Doğum haftalarında konuşmalar yaptı, sempozyumlarda bildiriler sundu; bunların birçoğu da yayımlandı. Erişebildiğimiz makale, bildiri ve konuşmalarını yayımlanma tarihlerine göre/kronolojik olarak şöyle sıralayabiliriz:

- "Niçin İslâm Felsefesi Vardır?", Ankara Üniversitesi İlahiyat Fakültesi Dergisi 20 (1975), 249-255.

3 Bunları kendisi tek tek ve ismen dizi editörü Nuh Muaz Kapan'a yazdırmıştır. 
- "Nietzsche Metafiziğinde Güç-İstemi (Wille zur Macht)”, Ankara Üniversitesi İlahiyat Fakültesi Dergisi 26 (1983), 241-257.

- “Nihilizm’in Tarihçesi”, Uludağ Üniversitesi İlahiyat Fakültesi Dergisi 1/1 (1986), $1-8$.

- Fârâbî, “Soyut Varlıkların İspatı”, çev. Hüseyin Aydın, Uludağ Üniversitesi İlahiyat Fakültesi Dergisi 1/1 (1986), 9-12.

- "ílahiyat Fakültelerinde Felsefe Öğreniminin Önemi ve Yeniden Düzenlenmesi”, Yüksek Öğretimde Din Bilimleri Öğretimi Sempozyumu, (21-23 Ekim 1987) (Samsun: Ondokuz Mayıs Üniversitesi İlahiyat Fakültesi Yayını, 1988), 319322.

- “Osmanlılarda Felsefî Düşünce”, Uludağ Üniversitesi İlahiyat Fakültesi Dergisi 4/4 (1992), 1-8.

- "Bir Mütefekkir Olarak Muhammed Hamdi Yazır", Elmalll Muhammed Hamdi Yazır Sempozyumu, (4-6 Eylül 1991) (Ankara: Türkiye Diyanet Vakfı Yayınları, 1993), 260-264.

- “Kur'an Açısından İnsan Hürriyetinin Temellendirilmesine Bir Yaklaşım”, Uludağ Üniversitesi İlahiyat Fakültesi Dergisi 6/ 6 (1994), 1-8.

- “Allah Tasavvuru ve Vahiy”, Hz. Muhammed ve Gençlik (Kutlu Doğum Haftası, 1992) (Ankara: Türkiye Diyanet Vakfı Yayınları, 1995), 191-193.

- "Filozof", Türkiye Diyanet Vakfi İslâm Ansiklopedisi (İstanbul: TDV Yayınları, 1996), 13/107-109.

- "Nübüvvetin İspatı ve (Nebilerin) Sembol ve Benzetmelerinin Te'vili Üzerine”, Uludağ Üniversitesi İlahiyat Fakültesi Dergisi 7/7 (1998), 565-573.

- “Tanzimat'dan Cumhuriyet'e Tanrı Tasavvurunda Yaşanan Değişmeler ve Deist İman”, Uludağ Üniversitesi İlahiyat Fakültesi Dergisi 8/8 (1999), 1-28.

- "Kusta b. Luka ve Ruh İle Nefs Arasındaki Ayırım Adlı Kitabı", Ankara Üniversitesi İlahiyat Fakültesi Dergisi 40 (1999), 387-402.

- "Etki ve Edilginin Kısımları: İbn Sina", çev. Hüseyin Aydın - Enver Uysal - Hidayet Peker, Uludağ Üniversitesi İlahiyat Fakültesi Dergisi 9/9 (2000), 623-629.

- "Vahiy Kültürünün İnsani Kültüre Dönüştürülmesi Zorunluluğu ve Sünnetin Önemi”, Diyanet İlmî Dergi - Peygamberimiz Hz. Muhammed (Özel Sayı) (Ankara: Diyanet İşleri Başkanlığı Yayınları, 2000; 2. bs., 2003), 225-238.

- "Avrupa Birliği Sürecinde İslâm ile Hıristiyanlık Arasındaki Teolojik Müștereklere ve Kültürel Farklılıklara Bir Bakış”, Türkiye'nin Avrupa Birliği’ne Girişinin Din Boyutu, (Sempozyum, 17-19 Eylül 2001) (Ankara: Diyanet İşleri Başkanlığı Yayınları, 2003), 263-272. 
- “Ahmet Hamdi Akseki'nin Felsefeye İlgisinin Boyutları”, Ahmet Hamdi Akseki (Sempozyum), yay. haz. Hüseyin Arslan - Mehmet Erdoğan (Ankara: Türkiye Diyanet Vakfı Yayınları, 2004), 17-19.

- "Vahiy Kültürünün İnsanî Kültüre Dönüştürülmesine Bir Örnek: Yüce Kur’an ve Açıklamalı-Yorumlu Meâli”, Uludağ Üniversitesi İlahiyat Fakültesi Dergisi 22/1 (2013), 1-28.

\section{Mezuniyet Yıllığı Kayıtlarında Hüseyin Aydın}

Prof. Dr. Hüseyin Aydın, Bursa Uludağ Üniversitesi İlâhiyat Fakültesi öğrencilerince hazırlanmış mezuniyet yıllıklarına yansıyan görüş ve düşünceleriyle bir akademisyen ve hoca olarak ayrıca dikkate alınması, irdelenmesi gereken bir şahsiyettir. Yıllık kayıtlarındaki malzeme ona ait vecizeler/nükteler, derslerdeki kısa açıklamalar dışında uğurlama yazıları, çeşitli sorulara verdiği cevaplardan derlenen bir röportaj ve ilâhiyatçı kimliği etrafında kaleme aldığı kısa yazılardan oluşmaktadır. Kimisi kendi dekanlık görev süresi içerisinde yazılmış yahut derlenmiş bu metinleri aynen iktibas etmekte yarar görmekle birlikte, bazı yönlerine de temas etmek istiyoruz:

Hüseyin Aydın, ilâhiyatçı olmaya dair yazılarında ilâhiyatçı olmanın güçlüğü, bu güçlüğün üstesinden gelmek için kendini sürekli yenileme ihtiyacı ve bilginin sağlam kaynaklara dayanması gereği üzerinde durmaktadır. Aydın'a göre ilâhiyatçı her görüşe açık ve müsamahakâr olmalıdır. İslâm'ın bütünlüğü dışında herhangi bir akıma gönül vermek, herhangi bir şahsa bağlanmak yanlıştır ve dar çerçeveye hapsolmak demektir. Bu, aynı zamanda ilâhiyatçının meslekî etkinliğini ve verimliliğini azaltan bir durumdur. İlâhiyatçı, millî birliğin korunduğu ve temsil edildiği güçlü bir devlet yönetiminde İslâm'ın değerlerinin daha iyi yaşanıp yaşatılabileceğini bilmeli ve devlete sahip çıkmalıdır. İlâhiyatçı, "değişmeyen değerleri değişen hayat içinde canlı tutmaya, etkin kılmaya çalışan kişidir.” Dolayısıyla hayatın mahiyetini iyi kavraması, bilgi donanımını genişletmesi elzemdir. Aydın'ın düşündüğü ve düşlediği ilâhiyatçı tipi budur. Dahası, ona göre, "hayatı, insanın yapı ve kaderine uygun bir şekilde belirlemek büyük ölçüde ilâhiyatçının görevidir."

Uğurlama yazıları bağlamında dile getirilecek ilk şey farklı bir hitap tarzının mevcûdiyetidir. Bir hoca olarak Hüseyin Aydın, mezuniyet aşamasına gelmiş öğrencilerini uğurlarken, onlara şahsiyet kazandırıcı bir üslûbu tercih ederek "değerli meslektaşlarım, genç meslektaşlarım, kıymetli meslektaşlarım” diye hitap etmekte; sonunda da çoğu kez "iyi haberlerinizi bekliyorum, iyi haberlerinizi beklerim" diyerek sözlerini tamamlamaktadır. Ona göre mezun olmanın tatlılı, acılı bir hazzı; bir burukluğu, ancak sorumluluk yükleyici bir yönü vardır. Mezunların göreve gidecek olması gurur vericidir, sevindiricidir. Zaten ilâhiyat eğitimi almanın amacı da budur. Ancak İlâhiyat mezunları görev şuuru içinde hareket etmelidir. Halka asla dogmatik ve mezhepçi, tarikatçı tavırla yaklaşmamalı; çoğulcu bakışın ifadesi olan fenomeno- 
lojik tavrı benimsemelidir. Buna göre her insan farklı bir bireydir. İnsan, farklı duyguları hatta çelişkileri bir arada yaşayan disharmonik bir varlıktır. Bu yüzden insanı anlamak, davranışlarının kompleks motivasyon yapısını kavramak ve onu iyiye, güzele yönlendirmek zor bir görevdir. Bunu başarmak için bilgi ve genel kültür gerekmektedir. Hüseyin Aydın, hayatın ve duyguların çeşitliliği içinde mezunlara, "kendinizi iyi tanıyın" tavsiyesinde bulunmakta; "ne olduğunuzu bilmeden olmanız gereken yere kendinizi ulaştıramazsınız" demektedir. Netice olarak illâhiyat mezunu, insanın bir imkânlar varlığı olduğunu bilmeli; sahip olduğu imkân ve yetenekleri kendi için belirlediği iyi hedefler istikametinde kullanmalı ve amacını gerçekleştirmelidir. Bunu yaparken insanı, hayatı, ülke gerçeklerini iyi kavramalıdır. Aydın'a göre karamsarlık, ümitsizlik yok. Hayat bir kere yaşanır; kıymeti bilinmelidir. Eğitim-öğretim kurumu mabed gibi kutsaldır. Birbirinin olmazsa olmazı durumundaki hoca-öğrenci ilişkisi ise insanî ilişkilerin en güzeli ve en verimlisidir. Göreve başlayacak mezunlar daha geniş bir platformda bu ilişkiyi sürdüreceklerdir.

Burada içerik özeti verilen yazılar hiçbir eksiltme ve değiştirme olmaksızın aşağıda sıralanmıştır.

\section{1. İlahiyatçı Olmaya Dair}

\subsection{1. İlahiyatçı Olabilmek}

"Birlikte ders yaptığımız anlarda sizlere sık sık 'ilâhiyatçı olmanın güç olduğunu' söylemiş ve bu güçlüğün de çok çeşitli kaynaklardan beslendiğini ifade etmeye çalışmışımdır.

[Bu kaynakların başında dinî bilginin ilmî bilginin kriterleriyle desteklenme arzusunun her çağdan daha fazla yüzyılımızın karakteristiği olmasıdır. Çünkü 17. yüzyıldan bu yana matematik-fiziğin elde ettiği başarıların 20. yüzyılda baş döndürücü sonuçlara ulaşması ile, varlık alanlarının karakterleri ve veriliş tarzları hakkında bir bilgi ve şuura sahip olmayan; ama belirli bir sınırdan sonra yine rölatif kalan matematik-fiziğin kesinliğini her alanda arayan fertler oldukça çoğunluktadır. Onlara her varlık alanının ayrı bir nev'i ve veriliş tarzı olduğunu, o varlık alanına ait bilginin kesinlik derecesinin varlık nev'i ve veriliş tarzına göre değiştiğini; dinî varlık alanının türü, karakteri ve veriliş tarzı ise tamamen ayrı bir mahiyet arz ettiğinden dinî bilginin kriterleri de matematik-fiziğin kriterlerinden apayrı olduğunu anlatmak ve göstermek oldukça zordur. Bu ontik ve gnoseolojik (epistemolojik) farkı görmeksizin yapılan bazı itirazları göğüslemeniz geniş bir kültürü ve sürekli olarak kendinizi bilgi yönünden yenilemenizi şart koşar.]

Hangi kaynaktan gelirse gelsin bu güçlükleri yenebilmek için kendinizi sürekli olarak yenilemek, geniş bir orientation'a sahip olabilmek için her türlü yayına açı olmak, dine karşı olan her türlü görüşe karşı hazımlı olup son derece müsamahakâr bir tavırla karşılamak başlıca şiarımız olmalıdır. Bu tavır ve anlayış ile karşılamanız 
gereken bu görüşleri aynı tavırla mahiyetlerinden kavrayıp, tartışmaları ve düşmanca bir anlamı ifade etmemek kaydıyla kullandığım ‘mücâdele'yi o görüşlerin alanında kabullenip, ilmî hesaplaşmayı orada yapmanızı tavsiye ederim.

Önemi bundan daha az olmayan diğer tavsiyem de hayatınızda İslâm'ın bütünlüğü dışında bir cereyana gönül verip, bir akımın dar çerçevesi içinde meslekî müessiriyetinizin daha verimli olacağı zehabına asla kapılmayın. Böyle bir akıma kendinizi kaptırmak, başka akımların da varlı̆̆ına cevaz verme sonucunu doğurur. Böyle bir tutum, bir şahsa bağlllığı ve İslâmiyeti bu şahsın kişiliğinde temsil ettirme saplantısını da beraberinde getirir. İslâm dininin ulvî prensipleri hiçbir eleştiriye konu olmayacak iken, eğer İslâm bir şahsın kişiliğinde temsili edilecek olursa, onun yaşayış biçimi ve kişiliği tenkit konusu olabileceği için, İslâm'ı da dolaylı bir biçimde eleştiri konusu yapmış olursunuz ki, VEBALDIR.

Meslek hayatınızda resmiyetin dışına asla çıkmayın, millî birlik ve beraberlik korunduğu takdirde devlet güçlü olur. Güçlü devlet hakimiyeti altında İslâm'ın değerleri daha geniş ölçüde yaşatılır ve yaşanır. Bu nedenle devlete sahip çıkın.

Hepinize etkili ve verimli bir vazife hayatı temenni ederim kıymetli meslektaşlarım." (1983-1984 Yll Mezunları Albümü) ${ }^{4}$

\subsection{2. Çağımızda İlahiyatçı Olmak}

Yıllık düzenleyicisi öğrencilerin hocalara yönelttiği soru, "Çağımızda Nasıl Bir İlâhiyatçı Düşünüyorsunuz?” şeklinde idi. Bu soruşturma için Hüseyin Aydın'ın cevabî nitelikteki yazısı şöyledir:

"Değerli meslektaşlarım,

Mesleğinizi resmen-fiilen icra etmek üzere sizleri uğurlarken nasıl bir ilâhiyatçı düşündüğüm konusunda yeni bir şey söyleyecek değilim. Çağımızın şartları içinde, ilahiyatçı olabilmenin ne kadar güç bir şey olduğunu, zaman zaman derslerimizde birlikte tartışıp değerlendiregeldik. Günümüzde ilâhiyatçı olmanın güçlüğünü, isteğiniz üzerine tekrar vurgularken, yine 'Hayat'tan söz edeceğim:

İlahiyatçı, değişmeyen değerleri değişen hayat içinde canlı tutmaya, etkin kılmaya çalışan kişidir. Hayat ise insanın kendisiyle, diğer insanlarla, kâinat ile ve Tanrı ile olan iliş̧kilerinin canlı bir bütünüdür. Bu ilişkilerin bilgisel niteliği değiştikçe, bu ilişkiler de değişir. Dolayısıyla hayat da değişir. Bu değişme iyi yönde de olur, kötü yönde de.

Bu değişme, ilişkilerin bilgisel niteliğinin değişmesinin yanında bu ilişkileri belirleyen, yönlendiren, yani determine eden değerlerin çeşitli kaynaklardan gelmesi ile

4 Köşeli parantez içindeki paragraf hariç bu yazı, bir sonraki yıl, yani 1984-1985 Yllı Mezunları Albümü’nde de aynen yer almıştır. 
de meydana gelir. Görülüyor ki hayat, mahiyeti gereği her zaman değişmeye maruz kalır.

Değişen, sürekli yeni boyutlar kazanan hayat, insanın yapı ve kaderine uygun bir şekilde belirlemek büyük ölçüde ilâhiyatçının görevidir. ílâhiyatçının bunu başarabilmesi için de hayatın bu mahiyetini iyi kavraması, bilgisel donanımını çok geniş kazanması, hayatı belirleyen ve beşerî dinî temele en uygun olan değerleri çok iyi görüp, duyup kollaması gerekir.

Ben istediğim, özlediğim ilahiyatçıyı nitelendirirken, aydın, ilerici.. gibi yuvarlak tabirler kullanmak istemiyorum. Hayatın mahiyetini, sade bir ifade ile 'Hayat'i anlayan, kavrayan ilâhiyatçıyı düşünüyorum, düşlüyorum." (1992-1993 Mezuniyet Ylllı̆ı)

\subsection{Uğurlama Yazıları}

1.

"Genç meslektaşlarım...

Mesleklerin en zorunu, sorumluluk derecesi en yüksek olanını, ama en şerefli olanını seçmiş, tahsil hayatını bitirmiş, yeni bir döneme başlıyorsunuz.

Fakülte hayatınızın son yılında yoğun bir şekilde dersinize girmiş bir hocanız olarak, yüklendiğiniz görevin gerektirdiği şuur üzerine yeni söyleyeceğim bir şey yok. Ancak şunu tekrar etmekten kendimi alamıyorum: İnsan hayatının merkezi değerleri olan dinî değerler üzerine eğitim ve irşad görevinizi yürütürken, halka asla dogmatik ya da mezhepçi, tarikatçı tavırla yaklaşmayın. Yaklaşımınız fenomenolojik tavır olsun. Çünkü toplum içindeki insanın individüalist karakterinden dolayı, aynı değerlerin duyuluşu, yeniden değerlendirilişi ve yaşanışı hemen hemen her insanda farklıliklar arzeder. Bu fenomeni, günümüzün geniş ve çeşitlenmiş kültürü besler. Böylesine çoğulcu bir toplumda kişinin ya da cemaatin kendi fenomenlerinden kalkarak onunla diyalog kurmaya çalışın.

Hakettiğiniz gayelerinize ulaşmanız temennilerimle uğurlarken, sizlerden iyi haberler bekliyorum." (1987-1988 Mezunları Yılliğı)

2.

“Sevgili öğrencilerim

Değerli meslektaşlarım,

Her yıl mezun öğrencilerimizi uğurlarken çok farklı duygular yaşarız. Bir taraftan sizlere alışmış, sizlerle ortak faaliyetlerimiz olmuş ve sizleri sevmiştik. Bu ayrılık bize zor geliyor. Diğer taraftan sizler gerekli formasyonu kazandınız, fakülteyi bitirdiniz, mesleğe hazırlandınız, göreve gidiyorsunuz. Amaçladığımız, ulaşmak istediğimiz de bu idi. Bu da bize gurur veriyor, kıvanç duyuyoruz. Isște sizleri bu karışık, farklı duygularla uğurluyoruz... 
İnsan farklı duyguları aynı anda yaşayan, farklı isteklerin peşinde aynı anda koşan, çok kez çelişkili davranışları peşpeşe sergileyebilen bir yapıya sahiptir. Sizleri uğurlarken böyle disharmonik bir varlığa sahip olan insan konusuna dikkatinizi bir kez daha çekmek istiyorum.

İște bu insan, çelişkilerle yüklü bir yapıya sahip olan bu insan ve onun ilişkilerinin yapı-düzeni sizin görev alanınızı ve bu alanın muhtevasını oluşturuyor. İnsanı anlamak, onun davranışlarının kompleks motivasyon yapısını kavramak ve ona eğitim yolu ile dinamizm kazandırmak; iyiye, güzele, doğruya yönlendirmek sizin görevinizdir. Bu ise son derece zor olan bir görevdir.

Önce insanı sevmesini, insanların bireyselliğini görüp onlara tahammül etmesini bilmek zorundasınız. Bu ise bilgi ve genel kültür ile olur. Ve bunun sonucu olarak da olgun insanlar olmak zorundasinız.

Sizleri bu dilek ve temennilerle uğurlar, kutsal görevinizde başarılar diler, hep iyi haberlerinizi beklerim." (1993-1994 Mezuniyet Yilliğı)

3.

"Sevgili meslektaşlarım,

Sizlere böyle hitap edebilmek biz hocalarınıza gurur ve haz verir. Bu hazzı bize yaşattığınız için, hem kendim hem hocalarınız adına sizlere teşekkür ederim.

Siz de mezun olma hazzını yaşıyorsunuz. Nedir bu mezuniyet hazzı? Bu hazzın anatomisi, kendimden bildiğime göre tatlılı, acılı, ekşili, tuzlu, turşulu bir sofrayı andirır.

Üniversite mezunu olmanın gurur, fakülteye girince hayal edilen 'mezun ideali'nin hâlâ erişilemeyecek yükseklikte olduğunun burukluğu, artık hayat üzerine bir sorumluluk duygusunun daha ağılıklı bir tarzda uyanması, hayatın bütün çeşitliliğgi ile daha belirgin bir şekilde önümüze serilmesi, istediğin yerde olup olamama tedirginliği... İşte bu duyguların içinde hayatın anlamı ve değeri yatmaktadır.

Hayatın bu kanaviçesi içinde önce kendinizi iyi tanıyın. Ne olduğunuzu bilmeden olmanız gereken yere kendinizi ulaştıramazsınız. Bu bir proje işidir. Projeler imkânlara göre yapılır. Ama şunu da gözden uzak tutmayın ki, 'Allah herkesi herşey için yaratmamıştır' desek de, insan bir imkânlar varlığıdır. Sahip olduğunuz imkân ve yetenekleri, kendinize iyi hedefler belirleyerek realize etmeye çalışın.

Bazı olaylara bakıp karamsarlığa düşmeyin, ümitsizliğe kapılmayın. İnsan varlığını, hayatın nedenselliğini, ülke gerçeklerini çok iyi kavrayın. Eskiden 'dünya küçük' deyimi bir fantezi olarak dile gelirdi. Bugün 'dünyanın küçüldüğ̈̈’ bir realite olarak yaşanıyor. Bunun da bilincinde olun.

Her bir anınızı, hayat tecrübesi olarak hayatınızın nedenselliğinin temeline koyun. İnsan hayatı üzerine çok dikkatli gözlem yapın. İnsan varlığının bütünlüğünde 
bulduğumuz ihtiyaç ve itilimleriasla dumura uğratmayı düşünmeyin, onları değerlerin yaşanmasının dinamikleri kılmağa çalışın. Bu hayat bir kere yaşanıyor. Kıymetini bilin.

Bu tavsiyelerim, temennilerimi de içermektedir. İyi haberlerinizi bekliyorum." (1996-1997 Mezunları Yıllığı)

4.

"Değerli meslektaşlarım,

Çalışmak görev, öğrenmek erdem ise, eğitim-öğretim kurumları mabed değil ama mabed gibi kutsaldır. Buralarda hoca-öğrenci birlikteliği, insan ilişkilerinin en iyisi, en güzeli ve en verimlisidir. Her ikisi de başarıya ve insanî olgunluğa ancak birlikte ulaşılır. Bunlar birbirlerinin olmazsa olmaz koşuludur.

Bu birlikteliğimizde, hepsinin ayrı bir değeri olan ilişkilerimiz olmuştur. Bunlar, hepimiz için çok güzel yaşantılar olarak hayatımızın örgüsünün önemli bir kısmını oluşturacaktır.

Bazı şeyler sona erer; ama hayat devam eder. Sizler hoca-öğrenci birlikteliğine, çok daha geniş bir platformda ve konum değiștirerek devam edeceksiniz.

Hepinizin her zaman iyi haberlerinizi duymak, başarılarınızı görmek isterim. Sizleri sevgilerimle uğurluyorum." (2001-2002 Mezunları Yıllığı)

\section{3. Öğrencilerce Derlenen Vecizeler-Nükteler-Kısa Açıklamalar}

\section{İnsan:}

"İnsan hareketlerini tek bir motife dayandıramazsınız. O, motifler kompleksidir." (1989-1990 Yillı̆̆1)

\section{Felsefe:}

- "Felsefe toplu bir dünya görüşü, küllî bir âlem sezgisidir."

- "Filozoflara göre insanın bir organı vardır, o da kafası."

- "Beyler, Yunan felsefesinde transandantal (aşkın, müteâl) tanrı anlayışı yoktur."

(Felsefe ile uğraşanlardan niçin çokça Allahsız çıktığı sorusuna cevap olarak:)

- "Felsefe ile uğraşanlardan çokça Allahsız değil, çok Allahlılar çıkmaktadır." (1993-1994 Yılliğı)

- “Rüyalarını görmeden felsefe öğrenilmez."

- "Beyler! Geniş düşünün. Bizler felsefe eşittir küfür yazıp sonra o dersi okutarak para kazanan hocalardan yetişerek buralara geldik.” (1992-1993 Yıllı̆̆ı) 
- "Beyler, metne bakarak konuşun. Ufkunuzu zorlayın, düşünün Fârâbî̀nin metinleri üzerinde konuşurken... "Bu felsefî metinleri sıradan insanlar anlayamaz. Ama Hüseyin Aydın gibi bir hocanız olduğu için şanslısınız.” (1991-1992 Yıllığı)

\section{Bilgi:}

- "İstemenin temelinde bilgi vardır."

- "Problemi olan insan denize düşen insan gibidir. Problemi çözebilmek için kendine gelen her bilgiye yapışır. İslâm filozoflarının yaptıkları da bundan ibarettir. Problemi olmayan insan statiktir."

- "Beyler, ümitlerinizi Batı medeniyetinin yıkılmasına bağlamayın; onu aşmaya çalışın!” (1993-1994 Yıllığı)

\section{Öğrenci:}

- “Öğrenci benim için her şeydir ama her şeyi yapamaz." (2001-2002 Ylllı̆̆)

\section{İlâhiyatçı:}

- "Tekrar dünyaya gelseydim yine ilahiyatçı olurdum."

- "illahiyat fakülteleri -felsefe ağırlıklı olarak- 6 yıl olmadan ölürsem gözüm açık gider." (1992-1993 Ylllı̆ı)

\section{Kur'ân:}

- "Beyler, Kur'an bir vahiy kültürüdür. İnsanî yorum, tefsir, tebyîn denilen şey devreye girmedikçe nassın direkt uygulanması mümkün değildir." (1993-1994 Ylllı̆ı)

İctihâd:

- "Beyler, ictihad devlet işidir. İctihad bir kanundur; ağzı, dili, topu tüfeği yoktur. İctihadın uygulanabilmesi için devlete ihtiyaç vardır.” (1993-1994 Ylllığı)

\subsection{Bir Röportajdan Yansıyan Düşünceler}

\section{Zor veya geç anlaşılan bir hoca olmak:}

"Alman filozofu Kant, 'Bir kitabın büyüklüğü sayfalarının çokluğu ile değil, anlaşılması için sarfedilen zamanın uzunluğu ile ölçülür' der. Bu çerçeve içinde niçin güç ve geç anlaşıldığımın takdirini size bırakıyorum."

\section{İyimser ve çareci olmak:}

İyimser ve çareci biri olduğu halde Felsefe dersinde neden farklı bir tutum izlediği yahut buna aykırı davrandığı sorusuna cevap olarak: “... Çok iyimser ve çareciyimdir. Çünkü insan ilişkilerine dayalı olayların birçok çözüm şekli vardır. Ben en kolay, kişiye en uygun olanını tercih ederim. Fakat Felsefe dersinden başarılı olmanın tek bir çaresi vardır: Felsefe ile asgarî düzeyde bir tanışıklık seviyesine ulaşmak. Bu konuda başka bir çare tanımam." 


\section{Felsefeci olmak:}

Hüseyin Aydın Müslüman bir felsefeci olmasaydı ne olmak isterdi? Cevabı şudur: “Yüzüm kızararak 'yine felsefeci olmak isterdim' diyorum. Çünkü ‘felsefeci' sıfatını hakedecek seviyede bir felsefeci olamadım. Onu gerçekleştirmek için yine felsefe öğrenimini seçerdim."

\section{Felsefe ve İlâhiyat:}

"Bizde Felsefenin dinin alternatifi olduğu ve dinî imana bütün tuzakların felsefeden geldiğine dair genel ve yanlış bir kanaat vardır. Bir de henüz öğrenci felsefe ile tanışmadan önce irkiliyor, yabancılık çekiyor. Oysa insanın varoluşunun amacı ve nedeni, varlığın bütün yönleri ile bilgi-anlam-değer boyutları içinde ilişkiye girmesidir. Bu, kendiliğinden gerçekleşmez. Geniş bir bilgi, derin bir düşünme ve şümullü bir sezgi ile gerçekleşir. Bu da felsefedir. Bu düşünme, sezgi ve bilgi seviyesine ulaşmak cehd ve gayret ister. Bu gayreti göstermekten kaçanlar, problemi olmayanlar ve problemden korkanlar felsefeye de yabancı kalırlar."

\section{İlâhiyat öğrencileri-hocaları ve atâlet:}

"Kendi kendimize dayanamayıp, bizim yerimize düşünen, geleceğimizi bizim adımıza teminat altına alan kişiler arıyoruz. Kişiliklerine ve fikrî, ilmî donanımlarına bakmaksızın buluyoruz da. Artık kendimiz görmüyor, kendimiz düşünmüyor ve kendimiz karar vermiyoruz. Başkalarının bilgi ve tecrübelerinden yararlanma ile teslimiyeti birbirine karıştırıyoruz. Sonunda da hımbıllaşıyoruz."

\section{Erdem nedir?}

“Erdem (fazîlet): İnsanın bütünlüğü çerçevesinde, doğru bir yaşayışı temin eden 'İyi'nin ne olduğunu bilmek; yapıp-etmelerinde bu iyiyi gerçekleştirmek; erişemeyeceğimiz ve bize ait olmayan şeylerden yüz çevirmektir."

\section{Farklı bir Laiklik tanımı:}

"Laiklik 'dünya için âhireti, âhiret için dünyayı terketmemektir'. Bu, Türkiye'de de böyledir ve böyle olması gerekir."

\section{Dünyevî ve uhrevî ideal:}

"Bu dünyada ulaşmak istediğim tek şey iyi bir insan, yeterli bir hoca olabilmektir. Uhrevî idealim Allah'ın lütuf ve mağfiretine bağlıdır."

\section{İlahiyat mezunu ve meslek seçimi:}

“Insanlar kendi individüel varlıkları içinde meslek seçimini kendileri yapar. Yalnız şunu ilave etmek isterim: Diyanet hizmetleri gayretli, ferâgatli ve yürekli insanların tercih edeceği iştir." 
"Sonuna kadar çalışmak istemediğiniz bir çalışma dalını seçmeyin. Seçince de her an değiștirebileceğiniz psikolojisinde olmayın. Prensip sahibi olun ve yapamayacağınız şeylere ‘hayır' demesini bilin. ‘Tek şey’ olun. Her şey için yaratılmadı̆̆ınızı bilin."

\section{Öğrenci ve eş:}

"Ben, birtakım özelliklere sahip hanım adayları peşinde koşmanızı değil, bulduğunuzla yetinmenizi tavsiye ederim. Hayatta hanımın, en yakın ve en büyük yardımcı olduğunu bilin." (1989-1990 Yıllı̆̆ı)

\section{Vefâtına Tarih}

Prof. Dr. Hüseyin Aydın'ın Vefâtına Tarih

Ne ileri ne geri şaşmaz ölçü o demde, Nîçe bugün çâresiz, Muhâsibî elemde, Nûn çıktı, gözü yaşlı, Elmalı'dan sefer var, “HOCA ERDİ RAHMETE” ol mâh-1 Muharremde.

$1493-50=1443$ 